\title{
Judit Sági \\ Perspectives in Corporate Social Actions and Social and Financial Performance
}

\section{Summary}

The conceptual framework of CSAs in Hungary is evolving in line with the international standards; however, there is a certain delay in conceptualising these actions into a strategic framework in private sector organisations. There seems to be a distinction between for-profit and non-profit stakeholders; the former are characterised by corporate social responsibility initiatives, whilst the latter rely on the sustainability of these initiatives. The author is aware of the fact that these phenomena are likely due to the country being an emerging economy in Europe, and argues that, in a broader context, social actions, if remaining segregated, are insufficient to solve civil society problems. With consideration to social needs (poverty and social inclusion), the arguments for the appropriate targeting and sustainability of CSAs are emphatic, and a shift towards a more strategic concept of social investment is essential. In this perspective, the author argues for the significance of knowledge transfer (i.e. from consultancy partners to civil organisations, or between for-profit organisations) in encouraging networking and increasing the forms of employee community engagement. At the end of the paper, the placing of a project (sign-language distant service to help disabled/deaf persons) into a sustainable and financially sound framework is described.

Journal of Economic Literature (JEL) codes: A13, B55, D64, I31, M14

Keywords: corporate social actions, corporate social responsibility initiatives, social investments

Dr JUDIT SÁGI, associate professor, Finance Department, Institute of Finance and Accounting, Budapest Business School, University of Applied Sciences (Sagi.Judit@ uni-bge.hu); ORCID: 0000-0003-4197-3530 


\section{INTRODUCTION}

Although not unknown to market participants in Hungary, this topic has been conceptualised in accordance with the international mainstream. There certainly is a gap in the relevant Hungarian literature, and in practice, the forum for corporate social actions is still taking shape: stakeholders no longer have the former links and strategic considerations are still missing from these corporate social actions (hereafter: CSA's). The purpose of this paper is to depict the Hungarian situation for CSAs, with specific focus on stakeholder action.

In this regards, the Hungarian financial authority has a major role in promoting CSAs, among others, in raising financial awareness and training people in financial and business administration. During the implementation of its Pallas Athena Public Thinking Programme, the National Bank of Hungary (Magyar Nemzeti Bank, MNB) set up a strategy to improve financial literacy and financial awareness, and to improve the underlying economic and social knowledge and the related institutional framework and infrastructure. Through its foundations (e.g. Foundation for the Public Good, or Foundation for Financial Awareness), it seeks to play a leading role in the renewal of professional education in economics and finance, and to connect with other institutions and experts while also developing collaboration networks both in and outside Hungary. In MNB's understanding, "corporate social responsibility represents a commitment towards an ethical contribution to sustainable economic growth and the preservation and promotion of cultural and intellectual value, all aimed at improving public satisfaction and the quality of life". In other words, the CSAs of a given institution "comprise voluntary acts aimed at responding to the social and environmental impacts of its operations on a moral basis, thereby contributing to the realisation of goals that serve the interests of the community involved" (National Bank of Hungary, 2014, p. 11).

The author first considers the background of CSAs in Hungary in general, and then the culture of family businesses and the Hungarian context of culture, i.e. the national culture. Bearing in mind the background and the theoretical framework of culture in Hungarian family businesses, the paper then highlights the current practices regarding CSAs in Hungary. Within the scope of this overview, these findings are then discussed and future directions for further research are suggested.

\section{THE FRAMEWORK OF CSAS IN Hungary}

The conceptual framework of CSAs has been taking shape in Hungary in line with the international standards. According to the recommendations of the Business Council for Sustainable Development in Hungary, a CEO-led business organisation, the complex interpretation of corporate sustainability encompasses the following (BCSDH, 2013):

- Strategic approach - the management of a company should draw up its business strategy with long-term and value-creating economic, environmental and social considerations included, and should provide the resources necessary for implementing such a strategy; 
- Responsible management - the executive incentive scheme should include environmental and social goals as well as economic ones;

- Ethical operations - the company should operate in a way that respects the law and is ethical (for example, endeavour to be free from corruption and provide fair employment);

- Respect for human values - the protection of human life and safety, equality and the right to a healthy environment to be basic values should be taken into consideration when business decisions are made;

- Environmental responsibility - the company should be committed to environmental sustainability and should extend this responsibility to the entire supply chain (suppliers, partners and customers);

- Transparent operations - information about the company's activities, economic, environmental and social impact and performance should be made available and the company should inform its partners in a regular and credible way;

- Partnership with stakeholders - when stakeholders are impacted by its operations, the company should aim to create mutual satisfaction and long-term cooperation and partnerships.

Among the largest companies in Hungary (accounting for $20 \%$ of the country's GDP, according to the Business Council for Sustainable Development in Hungary, hereafter "BCSDH"), an increasing number of managers (approx. 80\%) consider sustainable development and CSAs in a strategic approach. Good examples are changing product and service portfolios, the creation of shareholder value (Kucséber, 2019), the spread of social responsibility to the entire value chain and donations (Bakó, 2013). The largest improvements have been observed in ethical operations and transparency (Lentner et al., 2017), prompting zero tolerance towards bribery and corruption. The greatest challenges have remained in the government and in responsible management (Kiss, 2018); and there has been a delay in partnership with stakeholders. In the future, the players considered as having a key role in this respect of corporate responsibility are predicted to be the top managers of corporations. ${ }^{1}$

The various concepts of CSAs are reflected in different ways among the market participants in Hungary: in some cases, their actions result in a new business model for Corporate Social Responsibility (Szegedi, 2010), but in most cases they are only about to promote social benefits through donations. There is a certain delay in the conceptualisation of these actions into a strategic framework within private-sector organisations (especially SMEs), which is clear from the ad-hoc and short-term nature of most corporate actions (Hohnen, 2007, Chandler et al., 2017). The author believes that there should be a trend-driven need for CSAs, arising from the strategies of market organisations.

In practice, the challenges rising from the economic circumstances in Hungary contradict the above-mentioned trend-driven need for CSAs. According to the World Economic Forum's Competitiveness Reports, the country is ranked far behind developed ones when business sophistication is (and the macro-economic environment, governmental institutions and labour market efficiency are) considered. The most recent report discussed the most problematic factors in doing business in Hungary, 
and concluded that political instability, tax rates and tax regulations, inefficient government bureaucracy and corruption are the most significant (WEF, 2014). In an emerging economy the lack of supporting business environment hinders the build-up of a conceptualised CSA strategy, especially when the climate for enterprise does not entertain designs for innovation and business sophistication.

In order to mitigate the risk of failure by CSAs in emerging countries, in $2010 \mathrm{a}$ project called "Enhancing Transparency and Credibility of CSR Practices Through the Establishment of CSR Performance Assessment and Monitoring Systems in New EU Member States" began with the aim to enhance the transparency and credibility of CSR practices. The project successfully laid a basis for country-level CSR measurement and monitoring systems in selected EU member states, including Hungary.

Within this project a handbook was developed as a self-assessment tool of assistance to companies, since they plan to review their CSR policies and reporting practice. It might also be used by civil societies and other stakeholder groups looking for a background to benchmark a company's performance, or by auditors and other corporate advisers on CSR/CSA issues (Dobó and Pintér, 2018). It serves as a best practice, since self-assessment may be a mechanism for companies to measure and compare their own performances over time and against peers. Market organisations are able to tailor their approach to verification to fit in the corporate culture, the context, objectives and contents of their CSR strategies and commitments.

The main component of the self-assessment tool is a tailored questionnaire (UNDP, 2010). The questions are classified into five overall categories (Governance, Environment, Labour Relations, Community Relations and Business Environment), and go far beyond the boundaries of an organisation. Each question (indicator) is supplemented by a definition and additional explanations on criteria, documentation, methodology, relevance and practical tips for the users in scoring. In practice, market participants can apply this self-assessment tool with success. ${ }^{2}$

Chart 1: Self-assessment of CSR/CSA

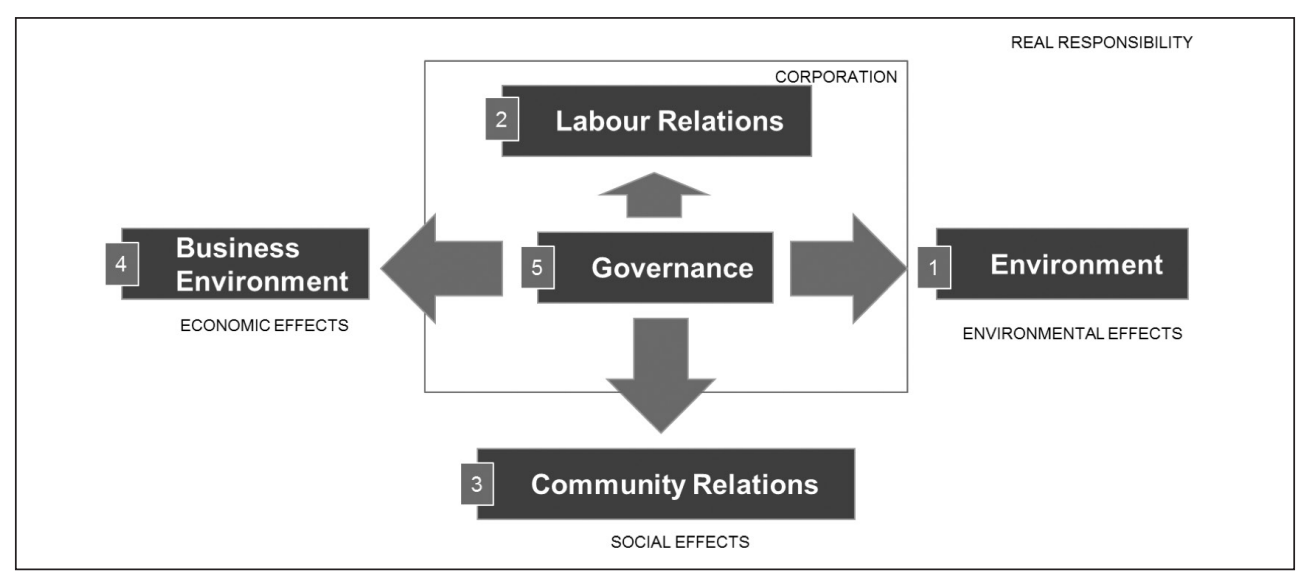

Source: Edited by the author on the basis of UNDP, 2010 


\section{Governance:}

- Does the company identify its main economic, social and environmental impacts?

- Does the company have a CSR strategy that defines its commitments to CSR?

- Does the company have designated senior personnel with a clear responsibility for CSR?

- Does the company link corporate responsibility issues to people's performance reviews/appraisals across the company?

- Does the company define key CSR priorities and communicate them throughout the organisation?

\section{Environment:}

- Does the company have action plans and programmes to lower its environmental impacts?

- Does the company maintain a monitoring system, measuring the main environmental impacts, especially resource usage and carbon emissions?

- Does the company have a training programme in place to help employees implement its environmental policy and action plan?

- Can the company show a quantifiable reduction in carbon emissions from the previous years?

- Does the company have a recycling programme?

\section{Labour relations:}

- Does the company have an action plan regarding labour/human resources and evaluate it on a regular basis?

- Do the employees have official representation in the company?

- Does the company have processes to prevent recurring problems regarding health and safety issues?

- Does the company have plans in place to mitigate the adverse impacts of job reductions?

- Does the company have an effective grievance procedure?

\section{Community relations:}

- Does the company have a community engagement action plan?

- Does the company engage in regular dialogue with its stakeholders?

- Does the company actively participate in CSR associations and forums and/or engage with any local NGOs?

- Does the company offer volunteering time, invest in or support any local community initiatives?

- Does the company offer apprenticeship schemes to facilitate skills development within the local community?

\section{Business environment:}

- Does the company assess significant suppliers and contractors on human rights, health and safety, anti-corruption and environmental practices? 
- Does the company engage in green procurement practices?

- Does the company have rules and procedures to analyse and counter bribery and corruption practices?

- Does the company have a policy and procedure for making its lobbying efforts transparent?

- Does the company train its staff on ethical supply chain measures and anti-bribery and anti-corruption measures?

As a conclusion, it has become evident that the recommendations made by the international mainstream encourage private sector organisations to formulate their CSA strategies. Although there is a certain delay in this respect, and the business environment is challenging the markets participants, the drive for CSA strategies is clear.

\section{THE NEED FOR SOCIAL ACTION}

The statistical indicators of poverty and social inclusion published by the Central Statistical Office of Hungary and according to Eurostat evidence need for social actions (Karcagi-Kováts, 2012). The composite indicator of (1) the number of people living in severe material deprivation and (2) the number of people living in households with low work intensity have seriously deteriorated throughout the past years in Hungary. The poverty rate of families with children has remained constant, since children are one of the main target groups of governmental measures designed to reduce poverty. Therefore, the first focus area of governmental interventions is the eradication of poverty and social exclusion. ${ }^{3}$ Young unemployed persons and healthcare workers are also included in the thematic focus.

The above-described redistributing function of the government does not contradict the responsibility taken by non-governmental stakeholders in these focal areas (Pintér, 2013; 2018; Pintér and Pintér, 2018). In fact, the extent and timing of privatesector actions is even more substantial in many cases (Carroll, 1983). Participants make investments to reflect social needs, whilst they are not primarily motivated by generating a direct financial return. However, questions remain as to whether CSAs reach the targeted social groups, and solely these ones, with the benefits (Szabó and Pinterr, 2015). Within the restrain of imperfect information, the question can be raised: Are social investment budgets spent as wisely as they could be, to generate the greatest possible social return?

The answer goes beyond pure philanthropy, towards a more strategic concept of social investments that involves the stakeholders' engagement and helping to understand the impacts on them by adequate measurements. Completing a social impact assessment can improve the understanding of the social, environmental and economic value that CSA programmes generate. The list of the questionnaire (consisting of 11 themed questions) elaborated by KPMG (2014, pp. 24-25) serves as best practice in this regard.

Within the framework of the corporation's strategy, the key questions to be addressed are: 
- What change do you want to create, and what impact do you hope to achieve?

- Why is your business investing in the areas it currently invests in, or plans to invest in?

- Who should benefit from the investments?

- How can progress be measured? What will success look like?

The questions concerning the transparency of social investments via reporting are:

- How can you most effectively communicate the story of progress against your objectives?

- Is the data and evidence reported robust and credible?

- What learning can you feed into your ongoing investment strategy, implementation and monitoring processes?

During the implementation, the key questions to be addressed are:

- Are all your current investment activities supporting your strategy? If not, can they be redesigned to better align with your objectives?

- Do you have the necessary budget and resources to implement, monitor and evaluate activities?

In the closing phase of monitoring and evaluation, the key questions are:

- Are there any existing sources of evidence for progress? For example, existing data on outcomes held by project partners, local government officials or community leaders.

- Are the benefits of your investment realistic? Have you considered the outcomes that could be attributed to other project partners?

Nonetheless, while planning investment into CSAs, certain criteria should be met, for example, those as listed below (KPMG, 2014, p. 15):

- CSAs need to be supported by effective partnerships between the market organisation and the community, the non-governmental organisations and the government;

- The social actions must be sustainable, originated from the organisation's strategy, and placing emphasis on social impacts;

- Investments into CSAs should be aligned with business objectives and local development priorities as well as internal functions that interact with local stakeholders;

- measures need to be established to quantify the business value of the investment and impact indicators, together with monitoring and evaluation;

- the value generated by the social investment should be communicated proactively internally and externally.

One outcome of the social impact assessment can be the build-up of stronger relationships with community stakeholders and project providers (partner organisations). This reflects the importance of an analysis of networking in CSAs.

\section{CURRENT PRACTICES IN NETWORKING}

AND SOCIAL ACTIONS IN HUNGARY

The organisations fostering (formal and informal) networking are described in this section. Among the participants, the Hungarian Business Leaders' Forum (HBLF) is a non-profit association and representative body of local business executives, 
local representatives of international joint ventures and other influential business people in Hungary. It is committed to promoting responsible business practices that benefit business and society, and which help to achieve social, economic and environmentally sustainable development in Hungary. This philosophy serves the interests of the companies, individuals and the society and supports the sustainable development of Hungary through the three pillars of sustainable development: economic, social and environmental well-being for the present and future generations. ${ }^{4}$

Within its aims, the Forum promotes partnerships with members to implement CSR projects and achieve their goals; opportunities for development; and the sharing of best practices and the measurement of results in the business sector. It raises awareness of improved business results in the practice of corporate social responsibility, and their impact on the economy. Furthermore, the Forum advocates sustainable development practices in order to establish healthier and improved conditions for future generations.

Practically, HBLF operates in workgroups; out of which the functions undertaken by the Partnership and Volunteering Workgroup and the Equal Opportunities Workgroup correspond to CSA networking. The former is a cross-sector collaboration (for employee volunteering, donations etc.) among for-profit and non-profit organisations. The latter wishes to draw people's attention to minority issues, especially relating to Romas, to support the equal treatment of all minorities beyond the existing laws and regulations (see also Hungarian Donors' Forum: MAF, 2011).

One of HBLF's initiatives that deserves special mention is the "Give \& Gain Day", which is a kind of corporate volunteering day. The idea came from Great Britain, where following the announcement of the British business organisation Business in the Community, thousands of employees carry out various volunteering activities due to the participation of hundreds of companies. The Hungarian event is organised by HBLF, the Hungarian partner of Business in the Community in the field of volunteering. On this day, for-profit and non-profit organisations perform useful work for smaller or larger recipient communities. The act of giving carries value not only for the recipient communities but it can also be a lasting experience for the colleagues. The Hungarian experience of corporate volunteering goes to show that such community actions provide a major development force for both the participating individuals and the whole community of associates.

Another organisation that has set the objective of assisting for-profit and non-profit organisation on the road to sustainable development in Hungary is the KÖVET Association. KÖVET (literally meaning "delegate", "envoy" or "someone on a mission") promotes environmentally aware business management and preventive environmental solutions to enterprises, and ensures an ongoing exchange of information primarily in the business sector. The organisation acts as a platform to find new ways for industry to reduce its environmental impacts and to promote their use as a basis for a competitive advantage. Their long-term goal is to assist organisations to become sustainable and responsible for society. ${ }^{5}$ 
KÖVET is the Hungarian member organisation of the International Network for Environmental Management (INEM), CSR Europe and the Global Footprint Network, through which it is linked to international sustainable business initiatives and projects. KÖVET is an institution that raises awareness and spreads the idea and tools of environmental management and corporate social responsibility.

Another networking organisation in Hungary is the Centre for Volunteering Association, which aims at assisting volunteers and their home organisations by providing information, counselling and training, as well as forming the philosophy of volunteering and integrating it into society. The Association has connections both with employees and their employing organisations.

Among its several programmes and initiatives, the Association plays a crucial role through operating a country-wide infrastructure of volunteering that locally coordinates projects, thus helping to meet private persons' willingness to contribute to meeting social needs. Besides this, the Association places emphasis on educating a wide range of people even including primary school pupils and developing their openness to volunteering. ${ }^{6}$

A comparison of these organisations' roles in networking reveals that they interpret the private sector's ability to take part in CSAs and thus respond to social needs in slightly different ways (EC, 2014). HBLF targets profitable corporations and guides them towards best practices in donations and volunteering. KÖVET helps corporations move towards preventive environmental solutions (Tóth, 2009). Finally, the Centre for Volunteering Association is prompting communication between volunteers and those who are in need of volunteers. However, all of these three organisations are committed to long-term sustainability and to the solutions that influence society in the long term.

Lastly, Pénziránytú Alapitvány ("Compass for Finance Foundation”) was established in Hungary in 2008 with the main purpose of elaborating and implementing programmes for enhancing financial literacy, in cooperation with for-profit and nonprofit organisations and governmental authorities as well. Its founders include the Student Loan Centre, the Hungarian Banking Association and the National Bank of Hungary. ${ }^{7}$ The mission of Pénziránytú Alapítvány is to help individuals and families by programmes to make informed financial decisions and improve the financial awareness of the population. The Foundation is a non-profit organisation with professional institutions with a reputation and expertise.

Over the years, the Foundation has implemented a number of programmes aimed at disseminating financial and economic knowledge in public education, i.e.: textbook development, content development, teacher training, a secondary-school and an elementary-school network, playful education and the PÉNZ7 (joined the European Money Week initiative).

As a first step in textbook development activities, in April 2016, the Foundation successfully approved its secondary-school textbook Iránytú a pénzügyekhez (Compass for Finance), which became the first official financial and economic textbook in Hungarian public education. Küldetések a pénz világában (Missions in the World of Money) is the second part of a series intrinsically linked to the modernisation of public education content. This book does not represent theoretical knowledge, but rather dis- 
seminates the logic of practical application, mobilising learners' experiences from everyday life and their families.

In line with governmental intent, the Foundation also attaches great importance to developing teachers' digital literacy and to the delivery of financial literacy through modern methods. Accordingly, the inclusion of e-learning and other digital applications in curriculum development has begun. The Foundation also runs successful inservice teachers' training programmes: the financial courses for secondary-school and primary-school teachers provide free training in several financial topics.

The school network is of great value to the Foundation, as the participating schools are committed to developing students' financial awareness. The BankVelem Financial Instructor Awareness Program offers a complex, hands-on teaching tool that combines sustainability and financial awareness, helps develop students' financial literacy in a playful environment, and contributes to the most important steps of online banking. The BankVelem Traveling School is unique and niche in domestic financial education, as a traveling coaching team "brings home" the player's financial education to schools. Under this program, the Traveling School visits 100 elementary schools each year to improve students' financial literacy through an interactive playhouse. It is important that the program reaches farther located and smaller schools, thus helping peripheral (less developed) areas to catch up.

The PÉNZ7 initiative has achieved remarkable results in recent years: in 2019, 1235 institutions reached more than 205,000 students in extra-curricular classes, doubling their first year access numbers. During a theme week, the Foundation provided full support to the financial lessons at the selected schools. This contributes to the success of the programme for 4 (primary and secondary) age groups, with lesson plans and aids developed by expert teachers and with professional materials to prepare teachers for the lessons, sample lessons and a webinar. The favourable perception of the Foundation's initiatives at schools, and the increasing interest and openness shown by institutions and teachers in financial and economic content are important achievements of the programme. Due to outstanding student participation by international standards, the Hungarian PÉNZ7 initiative received the Global Inclusion Award of the Child and Youth Finance International (CYFI) in 2017, and it was included in the most successful Global Money Week programmes in 2018 and 2019.

Raising the level of financial literacy in the domestic population was formulated as a public policy objective. An inter-institutional working group was set up to outline a comprehensive national strategy, in collaboration with the Foundation, the Ministry of Finance and the National Bank of Hungary. In their corporate social responsibility strategy these institutions have pledged take action in raising financial awareness (Tebeli, 2014).

\section{CONCLUSIONS AND FUTURE DIRECTIONS FOR RESEARGH}

This paper describes the way the need for corporate social action is linked to networking and how networking is also a crucial aspect of responsible institutions. There are some trailblazing associations in Hungary that offer slightly different solutions in 
responding to social needs. Based on employee community engagements, the author has identified a shift towards skill-based volunteering in the previous years (the benefits are presumably the highest in this form).

For CSAs, the government policy is to support awareness raising and - through the work of, among others, Pénziránytú Alapítvány - to contribute to the education of households. In this regards, CSAs are institutionalised along governmental initiatives.

Consent has been found among market participants to move towards a more strategic concept of social investments, which involves the stakeholders' engagement and is instrumental in understanding the impacts on them. Completing a social impact assessment can help size up the social, environmental and economic value that CSA programmes generate.

\section{Notes}

1 "We believe that the key to the long-term success of a company is having a CEO and a management team who are aware of the concept of sustainable development and are able to interpret it in a complex way during decision-making." István Salgó, President, Business Council for Sustainable Development in Hungary (BCSDH, 2013). "Having expressly declared sustainability principles at a company suggests leadership in strategic thinking, commitment and a high level operational culture.” Attila Chikán Jr., CEO, ALTEO Energy Services Plc. (BCSDH, 2013).

2 "What I have learned is that there is an abundance of policies in the company. Now reading them for the self-assessment makes me think that there is a need to streamline our policies and map the potential white spots. I am going to draw the attention of the relevant colleagues to this", revealed a large company representative from Hungary (UNDP, 2010).

3 The Hungarian government helps people with special social needs through a variety of care services. Special relief compensation and income support are available to those below a statutory income level for the payment of certain expenditures. Additionally, complex programmes promote the integration of disadvantaged children, including scholarship programmes in the case of multiply disadvantaged learners. The government is also about to adopt and continue a number of measures to prevent the passing on of social disadvantages and to promote social security. Improvement in the labour market prospects of disadvantaged groups is also of primary consideration.

4 The mission of HBLF is to encourage companies to integrate corporate social responsibility and the principles of sustainable development into everyday business practice. Members of HBLF promote responsible leadership for the long-term prosperity of their businesses and the whole of society.

5 www.kovet.hu/en/about-us.

6 www.oka.hu (Centre for Volunteering Association).

7 https://penziranytu.hu/magunkrol.

\section{REFERENCES}

Bakó, Cs. (2013): Vállalati felelósségvállalás a gyakorlatban [Corporate responsibility in practice]. Manuscript, IFUA Non-profit Partner.

BCSDH (2013): Recommendation for Business Leaders. BCSDH, https://bcsdh.hu/wp-content/uploads/2013/ 01/BCSDH_ajanlas_ENG_LowRes.pdf.

Carroll, A. B. (1983): Corporate Social Responsibility: Will Industry Respond to Cut-Backs in Social Program Funding? Vital Speeches of the Day, Vol. 49, pp. 604-608.

Chandler, N.; Heidrich, B. and Kása, R. (2017): Everything Changes? A Repeated Cross-Sectional Study of Organisational Culture in the Public Sector. Evidence-Based HRM, Vol. 5, No. 3, pp. 283-296, https:// doi.org/10.1108/ebhrm-03-2017-0018. 


\section{Civic Review · Vol. 15, Special Issue, 2019}

CSR Europe (2013): Golden Book. Celebrating CSR Partnerships, Innovation for Social and Business Impact. First European CSR Awards Project 2013. CSR, www.unglobalcompact.bg/wp-content/uploads/2014/05/Goldenbook.pdf.

Dobó, R. and Pintér, T. (2018): Az EU intézményrendszerének megítélése: Befolyásolás a kommunikációs csatornák népszerúsége és hitelessége által [The Public Opinion of the EU Institutions. Influence Through the Popularity and Authenticity of Communication Channels]. Polgári Szemle, Vol. 14, No. 4-6, pp. 226-239, https://doi.org/10.24307/psz.2018.1217.

EC (2014): National Social Report - Hungary, 2014. European Commission, http://ec.europa.eu/social/Blo bServlet?docId=11712\&langId=en.

Hohnen, Paul (2007): Corporate Social Responsibility. An Implementation Guide for Business. IISD, Winnipeg, www.iisd.org/pdf/2007/csr_guide.pdf.

Karcagi-Kováts, A. (2012): Performance Indicators in CSR and Sustainability Reports in Hungary. Applied Studies In Agribusiness And Commerce, Vol. 6, No. 3-4, https://doi.org/10.19041/apstract/2012/3-4/20.

Kiss, G. D. (2018): Default Probability of the Medical Imaging Service Providers in Hungary. Journal of Accounting and Management, Vol. 8, No. 2, pp. 115-128, https://hrcak.srce.hr/216260.

KPMG (2014): Unlocking the Value of Social Investment. KPMG International, https://home.kpmg/xx/en/ home/insights/2014/05/unlocking-value-social-investment.html.

Kucséber, L. Z. (2019): Egy céltársaság tulajdonosi értékelemzése irányításszerzô felvásárlás elôtt és után [Value chain analysis of a target company before and after acquisition]. In: Horváth, B. et al. (eds.): Közgazdász Doktoranduszok és Kutatók V. Nemzetközi Téli Konferenciája [Proceedings of the 5th International Winter Conference of PhD students and researchers in economics]. Szent István University, Gödöllô, pp. 371-378.

Lentner, Cs.; Szegedi, K. and Tatay, T. (2017): Social Responsibility in the Operation of Central Banks. Financial and Economic Review, Vol. 16, No. 2, pp. 64-85, https://doi.org/10.25201/fer.16.2.6485.

MAF (2011): Az alkalmazottak bevonásának lehetôségei lehetsegei a vállalati társadalmi befektetési programokba [Possibilities to involve employees into corporate social investment projects]. Magyar Adományozói Fórum [Hungarian Donors' Forum], www.donorsforum.hu/hu/publikaciok/2017-09-18-09-05-08/azalkalmazottak-bevonasanak-lehetsegei-a-vallalati-tarsadalmi-befektetesi-programokba-2011.

National Bank of Hungary (2014): Knowledge and Value. The Corporate Social Responsibility Strategy of the Magyar Nemzeti Bank. MNB, Budapest, www.mnb.hu/letoltes/mnb-csr-kiadvany-eng-final-1.pdf.

Pintér, T. (2013): Az európai integráció emberképe [Vision of the human being in the European integration]. In: Róbert, P. (ed.): Gazdaság és morál: tiszta társadalom, tiszta gazdaság. A 2012. június 12-i Kautz Gyula Emlékkonferencia válogatott tanulmányai [Economy and ethics: clean society and clean economy. Proceedings of the Gyula Kautz Memorial Conference held on 12 June, 2012]. Széchenyi István University, Gyôr, pp. 239-252.

Pintér, T. (2018): The Integration of Hungary into the European Union - Economic Aspects. Polgári Szemle, Vol. 14, Special Issue, pp. 165-183, https://doi.org/10.24307/psz.2018.0411.

Pintér, É. and Pintér, T. (2018): Magyarország integrációja az Európai Unióba - gazdasági és társadalmi megközelítés [Hungary's integration into the European Union - An economic and a social approach]. Új Magyar Közigazgatás, Vol. 11, Special Issue, pp. 1-10.

Szabó, D. R. and Pintér, T. (2015): The Polycentric Spatial Structure as a Basis for a Balanced Socio-Economic Structure. In: Nijkamp, P. et al. (eds.): CERS 2014. 5th Central European Conference in Regional Science. Technical University, Kosice, pp. 1007-1019.

Szegedi, K. (2010): The Concept and Development Tendencies of Corporate Social Responsibility. Theory, Methodology, Practice, Vol. 5, No. 1, pp. 67-74.

Tebeli, I. (2014): A hatékony állam kapcsolata a civil szervezetekkel, kiemelt figyelemmel a pénzügyi fogyasztóvédelemre [Relationship between the efficient state and civil societies, with special focus on financial customer protection]. Pro Publico Bono - Magyar Közigazgatás, Vol. 2, No. 1, pp. 194-203.

Tóth, G. (2009): The Truly Responsible Enterprise. About Unsustainable Development, the Tools of Corporate Social Responsibility (CSR) and a Deeper, Strategic Approach. KÖVET, Budapest, www.kovet.hu/en/. 
UNDP (2007): Baseline Study on CSR Practices in the New EU Member States and Candidate Countries. United Nations Development Programme, http://www.cbcsr.mk/Upload/Content/Documents/BASELINE_ STUDY_ON.pdf.

UNDP (2010): CSR Self-Assessment Handbook for Companies. United Nations Development Programme, www. spcc.pl/images/file/forums_workhops/csr_self_assesment_undp.pdf.

WEF (2014): The Global Competitiveness Report 2013-2014. World Economic Forum, www.weforum.org/reports/global-competitiveness-report-2013-2014.

\section{WEBS ITES:}

https://penziranytu.hu

http://sozialmarie.org/projects/development_and_maintenance_of_online_sign_language_dictionary.1455.html

http://vodafone.com/content/sustainabilityreport/2014/index/operating_responsibly/accessibility.html www.bodvalenke.eu/

www.erstestiftung.org/inside-the-foundation/mission-and-vision/good-bee/

www.hallatlan.hu/en/

www.hblf.org/english

www.horvath-partners.com/en/about-us/

www.oka.hu

www.wsis-award.org/winners/e-health-and-environment 